\title{
UNILATERAL DIAPHRAGMATIC PARALYSIS IN SPINAL CORD INJURY PATIENTS
}

\author{
By R. Edward Carter, M.D. \\ Rehabilitation Services, The Institute for Rehabilitation and Research, \\ I333 Moursund Avenue, Houston, Texas 77030, U.S.A.
}

\begin{abstract}
Since the inception of the Spinal Cord Injury Center of The Institute for Rehabilitation and Research in 196I, over I600 spinal cord injury patients have been admitted. Of these patients, approximately $5 \mathrm{I}$ per cent or $82 \mathrm{I}$ are tetraplegics. A review of the medical records shows that 22 patients had unilateral diaphragmatic paralysis. All but one of these patients are male, and they range in age from 15 to 73 years of age at onset. All cases with unilateral diaphragmatic paralysis are reviewed as to side of paralysis, incidence of tracheotomy, initial vital capacity, final vital capacity, and estimation as to the duration of diaphragmatic paralysis.
\end{abstract}

Key words: Spinal cord injury; Diaphragmatic paralysis; Tetraplegic; Respiratory insufficiency.

THE total population of spinal cord injured patients who have been admitted to The Institute for Rehabilitation and Research (TIRR) was reviewed. This study involved I6I3 patients of whom $5 \mathrm{I}$ per cent or $82 \mathrm{I}$ were tetraplegics on admission. Four per cent or 66 of these tetraplegics were admitted essentially apnoeic with neurologic levels of $\mathrm{C}_{3}$ and above and with no spontaneous respiration. A review of the charts of the patients with neurologic levels of $\mathrm{C}_{4}$ and below revealed a total of 22 patients who sustained permanent or transient unilateral diaphragmatic paralysis. These 22 patients are reviewed according to age, sex, etiology of injury, bony injury, neurologic level, right or left diaphragmatic involvement, recovery time, and whether or not diaphragmatic involvement was transient or permanent.

\section{Results}

Twenty-two patients with neurologic levels of $\mathrm{C}_{4}$ and below are identified as having unilateral diaphragmatic paralysis. Twenty-one patients are male, and one is female. These patients range in age at onset from 15 years to 73 years with an average age at onset of 32 years. In this study, three patients are paraplegics, and I9 are tetraplegics. For the purpose of this discussion, the patients are divided into three groups. Group I consists of six patients whose injury was the result of penetrating gunshot wounds. Group II consists of one patient who had direct trauma to the chest that resulted in a ruptured diaphragm and paraplegia. Group III consists of I5 tetraplegic patients whose injuries were the result of closed trauma to the neck.

In Group I, six patients were injured secondary to gunshot wounds which resulted in two paraplegias and four quadriplegias. The Group II patient was a paraplegic who was injured in a motor vehicle accident and had a ruptured and paralysed diaphragm and a lacerated spleen. Postoperatively, he was found to have a Tro paraplegia. In Group III, 12 of the 15 patients sustained a fracture 
dislocation of the cervical spine. In three patients no bony fracture was evident although these three patients each had a neurological level at $\mathrm{C}_{4}$.

\section{Aetiology}

The aetiology of injury of the Is patients in Group III with closed trauma revealed that six injuries were due to motor vehicle accidents; four due to falls; three resulted from diving accidents; one was the result of a football injury; and one was the result of the patient being hit by a falling tree.

\section{Vertebral level}

A study of the bony lesions involved in the I5 Group III patients revealed that three patients had no vertebral fracture demonstrable on X-ray film. One patient had a fracture dislocation of $\mathrm{C}_{3}$ on $\mathrm{C}_{4}$; four patients had a fracture dislocation each of $\mathrm{C}_{4}$ on $\mathrm{C}_{5}$; and seven patients had a fracture dislocation of $\mathrm{C}_{5}$ on C6. The corresponding bony levels and neurologic levels are indicated in Figure $\mathrm{I}$.

TABLE I

\begin{tabular}{|c|c|c|c|c|c|}
\hline & Age & Sex & $\begin{array}{c}\text { Bony } \\
\text { interval }\end{array}$ & $\begin{array}{c}\text { Neurol. } \\
\text { level }\end{array}$ & Duration \\
\hline Group I & $\begin{array}{l}24 \\
30 \\
20 \\
15 \\
37 \\
41\end{array}$ & $\begin{array}{l}M \\
M \\
M \\
M \\
F \\
M\end{array}$ & $\begin{array}{l}- \\
z \\
- \\
-\end{array}$ & $\begin{array}{l}\mathrm{C}_{4} \\
\mathrm{C}_{5} \\
\mathrm{C}_{4} \\
\mathrm{C} 8 \\
\mathrm{~T}_{3} \\
\mathrm{~T}_{9}\end{array}$ & $\begin{array}{l}\text { Transient } \\
\text { Permanent } \\
\text { Permanent } \\
\text { Permanent } \\
\text { Permanent } \\
\text { Permanent }\end{array}$ \\
\hline Group II & I6 & M & - & Tio & Permanent \\
\hline Group III & $\begin{array}{l}73 \\
22 \\
18 \\
54 \\
16 \\
19 \\
46 \\
18 \\
17 \\
30 \\
32 \\
27 \\
57 \\
69 \\
26\end{array}$ & $\begin{array}{l}M \\
M \\
M \\
M \\
M \\
M \\
M \\
M \\
M \\
M \\
M \\
M \\
M \\
M \\
M\end{array}$ & $\begin{array}{l}\mathrm{C}_{3}-4 \\
\mathrm{C}_{4}-5 \\
\mathrm{C}_{4}-5 \\
\mathrm{C}_{4}-5 \\
\mathrm{C}_{4}-5 \\
\text { C5-6 } \\
\text { C5-6 } \\
\text { C5-6 } \\
\text { C5-6 } \\
\text { C5-6 } \\
\text { C5-6 } \\
\text { C5-6 } \\
\text { No Fx. } \\
\text { None } \\
\text { None }\end{array}$ & $\begin{array}{l}\mathrm{C} 4 \\
\mathrm{C} 5 \\
\mathrm{C} 4 \\
\mathrm{C} 4 \\
\mathrm{C} 4 \\
\mathrm{C} 6 \\
\mathrm{C} 5 \\
\mathrm{C} 6 \\
\mathrm{C} 6 \\
\mathrm{C} 6 \\
\mathrm{C} 6 \\
\mathrm{C} 5 \\
\mathrm{C} 4 \\
\mathrm{C} 4 \\
\mathrm{C} 4\end{array}$ & $\begin{array}{c}\text { Transient } \\
\text { Transient } \\
\text { Transient } \\
\text { Transient } \\
\text { Transient } \\
\text { Transient } \\
\text { Transient } \\
\text { Transient } \\
\text { Transient } \\
\text { Transient } \\
\text { Transient } \\
\text { Transient } \\
\text { Transient } \\
\text { Transient } \\
\text { Transient }\end{array}$ \\
\hline
\end{tabular}

\section{Involved diaphragm}

Gunshot wounds to the neck resulted in two patients with paralysis of the right diaphragm and two of the left diaphragm. Gunshot wounds to the thorax produced one right and one left diaphragmatic paralysis plus the patient with the ruptured left diaphragm. Of the patients with closed traumatic injuries to the 
cervical cord, ten patients had diaphragmatic paralysis on the left side, and five patients had paralysis on the right side.

\section{Permanence}

Gunshot wounds to the neck or thorax plus direct trauma to the thorax as in the patient with the ruptured diaphragm produced permanent unilateral diaphragmatic paralysis in all but one patient. This patient received a gunshot wound to the neck which resulted in a neurologic level of $\mathrm{C}_{4}$ lesion and a transient right diaphragmatic paralysis. Of the 12 patients with fracture dislocation of the cervical spine plus three patients with no demonstrable fracture but neurologic levels of $\mathrm{C}_{3}-4$, all had transient diaphragmatic paralysis on either the right or left side.

\section{Vital capacity}

In the 22 patients in this study who sustained unilateral diaphragmatic paralysis from whatever cause, the initial vital capacity averaged IoI9 cc. The highest achieved vital capacity averaged 2I2I cc. The average recovery time was approximately 76 days in the 16 patients with transient diaphragmatic paralysis. In the six patients with permanent diaphragmatic paralysis, their average initial vital capacity was $1069.5 \mathrm{cc}$. They attained an average maximum vital capacity of $\mathrm{I} 86 \mathrm{I} \cdot 6 \mathrm{cc}$ in an average of 56 days.

A previously published paper reports recovery time in tetraplegics with transient apnoea in which their average maximum vital capacity of I I $8 \mathrm{cc}$ was attained in an average of 106 days (Carter, 1977). This same study reports motor complete $\mathrm{C}_{4}$ tetraplegics who were admitted with a vital capacity under $1000 \mathrm{cc}$ and attained an average of 1 I $67 \mathrm{cc}$ increase in vital capacity in an average of 75 days.

\section{Discussion}

The pathology of the diaphragmatic paralysis in Group I (six patients) is explainable in that these patients were injured due to gunshot wounds, four in the neck and two in the upper and mid-thoracic area. Because all but one of these were permanent injuries to the diaphragm, one could postulate either direct trauma to the phrenic nerve or possible disruption to nutrient arteries supplying the phrenic nerve on the involved side resulted in a permanent paralysis. Following a motor vehicle accident, the Group II patient was discovered to have a ruptured diaphragm on the left side as well as having a lacerated spleen. Post-surgery he was found to be a T Io paraplegic with no bony vertebral fracture. In this case, a direct disruption of the phrenic nerve could be suspected.

In the remaining I 5 patients, three had no discernable vertebral fracture; one injury resulted from a $\mathrm{C}_{3}-4$ fracture dislocation; and four patients sustained fracture dislocations at $\mathrm{C}_{4}-5$. Three of these patients with $\mathrm{C}_{4}-5$ vertebral fractures had $\mathrm{C}_{4}$ neurologic levels, and one patient had a $\mathrm{C}_{5}$ neurologic level. Seven patients had a fracture dislocation of $\mathrm{C}_{5}$ on C6. In the I5 patients in Group III, the exact pathophysiology is uncertain.

An ascending swelling of the spinal cord, unilateral nerve root injury, or intramedullary haemorrhage on one side of the spinal cord might affect the anterior horn cells of the phrenic nerve unilaterally. However, severe nerve root injuries should result in more permanent paralysis. Another possibility is anatomical variations with the majority of phrenic nerve innervation coming from other than 
the $\mathrm{C}_{4}$ nerve root. However, seven patients sustained a fracture dislocation of $\mathrm{C}_{5}$ on C6 with almost all having their last preserved motor segment at C6.

In these cases, because the diaphragmatic paralysis occurred immediately or within a few hours of the original trauma, then the damage to the phrenic nerve was probably due to the force of the injury. Because most of the patients' injuries resulted from severe flexion injuries with possibly some element of rotation, this severe motion may have transiently damaged one of the phrenic nerves. Only one of our patients sustained unilateral diaphragmatic paralysis at a point considerably post-trauma (four weeks). This patient's transient paralysis lasted the longest (I4 months) before return of function was noted in that diaphragm. The etiology was perhaps thought to be secondary to stretching of the phrenic nerve by a prolonged excessive amount cervical traction. This patient's case report is presented.

The resulting effect of unilateral diaphragmatic paralysis in a quadriplegic who has already suffered bilateral intercostal paralysis is a further decrease in vital capacity, increase in bronchio-pulmonary shunting, a low arterial oxygen saturation, and most importantly, the predisposition toward atelectasis and pneumonitis or both beginning in the base of the lung on the side of the diaphragmatic paralysis. Unilateral diaphragmatic paralysis should be suspected in all patients who demonstrate a lower vital capacity than anticipated, lower arterial oxygen saturation than anticipated, or a higher than normal position of the diaphragm on routine chest $\mathrm{X}$-ray films. Fluoroscopy tests can be readily obtained and can be read to confirm the diagnosis of lack of excursion of either diaphragm. In the event the patient is in cervical traction, a routine chest X-ray film can be taken with a double exposure. One exposure is taken in full inspiration, and the other taken in full expiration. In this manner, each diaphragmatic excursion can be delineated and measured.

\section{Case Report}

This patient was a 30-year-old male who was involved in a motor vehicle accident on I3 November I974. He apparently lost consciousness for several hours and woke up in the local emergency room. An L-shaped laceration over the forehead was found with a smaller laceration of the tip of the nose. X-ray films revealed a fracture dislocation of C5 over C6. Neurologic examination showed a C6 sensory level bilaterally and a C6 motor level tetraplegia. The spinal cord lesion was both motor and sensory complete. Tomograms demonstrated a fracture of transverse process of $\mathrm{C}_{7}$ and $\mathrm{T}_{\mathrm{I}}$. A fractured transverse process was evident at $\mathrm{T}_{2}$ with separation of $\mathrm{T}_{\mathrm{I}}$ and $\mathrm{T} 2$ from the ribs. He was placed in tongs with 80 pounds of traction. The fracture was not reduced; therefore, he underwent general anaesthesia and manual manipulation to reduce the fracture.

The patient was transferred to TIRR on 2I November 1974. He remained in 15 pounds of cervical traction which was reduced to ten pounds on I I December 1974. The traction was removed on 19 December 1974. Initial vital capacity on three occasions was 2300 to $2400 \mathrm{cc}$. However, between 9 December and I6 December 1974, essentially one month post-injury, his vital capacity dropped by 50 per cent to a level of 1000 to I IOO cc. Double exposure chest X-ray films revealed a right diaphragmatic paralysis. One week later, he developed a possible deep vein thrombosis which turned out to be a heterotopic ossification near the medial distal left femur. Upon discontinuing traction, the patient had difficulty sitting upright for a length of time because of dyspnoea. An abdominal binder underneath his corset enabled him to sit up for five hours at a time. The patient experienced significant fatigue following this sitting time.

The patient suffered no further complications and was discharged on 28 March 1975. $\mathrm{He}$ was functioning at a C6 motor level with an external catheter and with sterile urine. Readmission to TIRR was 8 July to 2I August 1975. Examination showed no change in his neurological findings. The diaphragmatic paralysis on the right persisted. Nerve stimulation to the right phrenic nerve produced a faint EMG of the diaphragm on the 
right. The diaphragm did not move, however, either by stimulation by single current or a train of percutaneous electrical stimuli. Because of extreme fatigue with minimal amount of sitting, he was placed on a pneumobelt for use in the wheelchair, and then he was discharged.

He was seen in the TIRR Outpatient Clinic on 12 December 1975. He had a tidal volume sitting with a pneumobelt of $650 \mathrm{cc}$; his vital capacity with the pneumobelt turned off was $1000 \mathrm{cc}$. When next seen for follow-up on 12 March 1976, he reported a 3-week history of feeling stronger and being able to wean himself from the pneumobelt. A fluoroscopy test showed one interspace movement of the right diaphragm, and his vital capacity was $\mathrm{I} 800 \mathrm{cc}$ in the sitting position. On subsequent follow-up to the year 1979 vital capacity consistently ranged from $2000-2200$.

\section{Review of literature}

The effects of artificial interruption of phrenic nerve were studied extensively and were described by Schroeder in 1902. Sporadic cases of spontaneous paralysis of the diaphragm were reported rarely thereafter; most patients who were reported on died. Most of the deaths were due to mechanical interruption of the phrenic nerve either by surgical intervention or by trauma. Therapeutic interruption of the phrenic nerve was at one time thought to be a valuable procedure in the treatment of tuberculosis; the practice of this theory accounted for the overwhelming majority of the cases encountered.

Kahn (I953) reported a 'spontaneous' paralysis of the diaphragm in a patient with an established diagnosis of pulmonary tuberculosis. Douglass and Clagitt (I960) surveyed the Mayo Clinic records of patients who were examined since I935 and described 59 patients with ideopathic diaphragmatic paralysis. Some degree of recovery was observed spontaneously in nine of the 27 traced patients in their series.

Riley (1962) stated that the most common cause of spontaneous unilateral paralysis of the diaphragms involving the phrenic nerve was by tumour either metastatic to the mediastinum or primary bronchogenic carcinoma. He also listed 23 other causes of unilateral diaphragmatic paralysis. However, association with traumatic spinal cord injury was not noted in this series.

Ridyard and Stewart (1976) reported regional lung function in five patients with unilateral diaphragmatic paralysis; four had diaphragmatic paralysis on the right side and one of the left side. These cases were unassociated with intrathoracic disease. All patients showed a reduction of total lung capacity to which the affected side contributed an average of 37 per cent.

Guttmann and Silver (1975) reported a patient with $\mathrm{C}_{5}$ tetraplegia with greatly reduced function of the right diaphragm one and a half months post injury. They also reported one patient with tetraplegia $\mathrm{C}_{4}$ on the left and $\mathrm{C}_{5}$ on the right with left diaphragmatic paralysis who had return of diaphragmatic function in 20 days. A second similar case was a patient with paralysis of the right diaphragm who had an initial vital capacity of $400 \mathrm{cc}$ and recovery of diaphragmatic function by the 27th day. The third patient was a motor $\mathrm{C}_{3}$ left and $\mathrm{C}_{5}$ right quadriplegicwho had complete left diaphragmatic paralysis three and a half months after injury. In the three recorded cases in the article by Guttmann and Silver, the average initial vital capacity was $483 \mathrm{cc}$, and the highest vital capacity average was I433 cc which was obtained in an average time of 123 days.

\section{SUMMARY}

Of a total of I6I3 spinal cord injury patients seen at TIRR between I960 and 1978, 22 patients were found to have unilateral diaphragmatic paralysis. Nineteen 
patients were tetraplegics, and three were paraplegics. Penetrating injuries (gunshot) wounds resulted in permanent unilateral diaphragmatic paralysis in five of six patients. One patient had direct chest trauma with a ruptured and permanently paralysed diaphragm. Fifteen patients with closed trauma to the neck plus one patient with a gunshot wound to the neck had transient unilateral diaphragmatic paralysis. The left diaphragm in this group of patients was involved twice as often as the right one was involved. The average initial vital capacity was IOI9 $\mathrm{cc}$ in patients with one paralytic diaphragm. A brief history of a traumatic C6 tetraplegic is presented plus a brief review of the literature and possible mechanisms of the paralysis. Recognition of this entity is of extreme importance in preventing needless atelectasis or pneumonia or both.

\section{RÉSUMÉ}

Parmis I6I3 traumatisés de la moelle épinière, examinés a TIRR entre I960 et I978, une paralysie unilatérale du diaphragme fut diagnostiquée chez I9 tetraplégiques et 3 paraplégiques. Chez 5 malades, la paralysie permanente unilatérale du diaphragme fut produit par la blessure pénétrante des armes à feu. Une rupture du diaphragme avec une paralysie permanente fut produite par une blessure de la cage thoracique. Une paralysie unilatérale transitoire du diaphragme fut produite chez I 5 malades par un trauma non ouvert du cou, et chez un $16^{\mathrm{e}}$, par une blessure au cou, due à un coup de fusil. En vue de ces résultats, il semble qu'en général les paralysies unilatérales diaphragmiques produites par des traumas non ouverts, sont transitoires tandis que celles produites par des blessures pénétrantes, comme celles des armes a feu, sont bien plus souvent permanentes.

Dans ce groupe de malades, le diaphragme gauche fut paralysé deux fois plus souvent que le droit. La capacité vitale des malades avec une paralysie unilatérale était en moyenne de IOI9 millilitres. La description d'un malade avec un trauma au niveau de la $6^{\mathrm{e}}$ vertèbre cervicale est présentée, avec une brève revue de la littérature pertinente et une description sur les mécanismes en jeu; le diagnostique de cette complication est très important pour éviter les atélectases pulmonaires et les pneumonies.

\section{ZUSAMMENFASSUNG}

Zweiundzwanzig von I6I3 Patienten mit Rückenmarkverletzungen, die zwischen 1960 und 1978 im Institut für Rehabilitation und Research untersucht wurden, hatten einseitige Zwerchfellähmung. Neunzehn davon waren tetraplegisch, drei paraplegisch. Penetrierende Verletzungen (Schusswunden) resultierten in permanenter einseitiger Zwerchfellähmung in fünf von sechs Fällen. Ein Patient hatte eine direkte Brustverletzung mit gerissenem und permanent paralysiertem Zwerchfell. Fünfzehn Patienten mit geschlossenen Verletzungen im Bereich der Halswirbelsäule und ein Patient mit einer Schusswunde im gleichen Bereich zeigten vorübergehend einseitige Zwerchfellähmung. Man sollte deshalb davon ausgehen, dass Zwerchfellähmungen von Patienten, die nichtpenetrierend verletzt wurden, von vorübergehender Natur sind. Patienten mit penetrierenden Verletzungen wie Schusswunden, die einseitige Zwerchfellähmung verursachen, bleiben dagegen in Bezug auf das Zwerchfell häufiger dauergeschädigt.

Die linke Zwerchfellseite war in der besprochenen Gruppe von Patienten häufiger betroffen als die rechte. Patienten mit einseitiger Zwerchfellähmung hatten durchschnittlich eine Vitalkapazität von IOI9 $\mathrm{cm}^{3}$. Die Krankengeschichte eines C-6 tetraplegisch Gelähmten wird kurz berichtet, einschlägige Literatur besprochen und mögliche Mechanismen der Lähmung diskutiert. Richtige Beurteilung des ganzen Fragenkomplexes ist von höchster Bedeutung, wenn unnötige Atelektase oder Pneumonie verhindert werden sollen.

\section{Acknowledgement}

Carol A. Smith, B.A., assisted with the preparation and editing of this manuscript.

\section{REFERENCES}

CARTER, R. E. (1977). Etiology of traumatic spinal cord injury. Statistics of more than I IOO cases. Tex. Med., 73, 6I-65. 
Douglass, B. E. \& Clagett, O. T. (1960). The prognosis in idopathic diaphragmatic paralysis. Diseases of Chest, 37, 294-297.

GutTMANN, L. \& Silver, J. R. (I975). Electromyographic studies on reflex activity of the intercostal and abdominal muscles in cervical cord lesions. Paraplegia, 3, I-22.

KaHN, M. (1953). Temporary 'Spontaneous' paralysis of the diaphragm. Diseases of Chest, I4, I04-IO9.

RIDYARD, J. B. \& STEWART, R. M. (1976). Regional lung function in unilateral diaphragmatic analysis. Thorax, 3I, 438-442.

RILEY, E. A. (I962). Idiopathic diaphragmatic paralysis. A report of eight cases. Am. $\mathcal{F}$. Med., 32, 404-4I6.

SCHROEDER, W. E. (I902). Phrenic nerve injuries. Am. f. Med. Sc., 123, I96. 